\title{
Roles and potential therapeutic targets of the ubiquitin proteasome system in muscle wasting David Nury ${ }^{1}$, Christine Doucet ${ }^{2}$ and Olivier Coux ${ }^{* 1,3}$
}

\author{
Address: ${ }^{1}$ CRBM-CNRS UMR5237, IFR22, 1919 route de Mende, 34000 Montpellier, France, ${ }^{2}$ Molecular and Cell Biology Laboratory, Salk \\ Institute, 10010 North Torrey Pines Road, CA 92037-1099 La Jolla, USA and ${ }^{3}$ CRBM-CNRS, 1919 route de Mende, 34293 Montpellier cedex 5, \\ France \\ Email: David Nury - david.nury@crbm.cnrs.fr; Christine Doucet - christine.doucet@crbm.cnrs.fr; Olivier Coux* - olivier.coux@crbm.cnrs.fr \\ * Corresponding author
}

Published: 22 November 2007

BMC Biochemistry 2007, 8(SuppI I):S7 doi:10.1 186/147I-209I-8-SI-S7

This article is available from: http://www.biomedcentral.com/I47I-209I/8/SI/S7

(c) 2007 Nury et al.; licensee BioMed Central Ltd.

This is an open access article distributed under the terms of the Creative Commons Attribution License (http://creativecommons.org/licenses/by/2.0), which permits unrestricted use, distribution, and reproduction in any medium, provided the original work is properly cited.

\begin{abstract}
Muscle wasting, characterized by the loss of protein mass in myofibers, is in most cases largely due to the activation of intracellular protein degradation by the ubiquitin proteasome system (UPS). During the last decade, mechanisms contributing to this activation have been unraveled and key mediators of this process identified. Even though much remains to be understood, the available information already suggests screens for new compounds inhibiting these mechanisms and highlights the potential for pharmaceutical drugs able to treat muscle wasting when it becomes deleterious. This review presents an overview of the main pathways contributing to UPS activation in muscle and describes the present state of efforts made to develop new strategies aimed at blocking or slowing muscle wasting.
\end{abstract}

Publication history: Republished from Current BioData's Targeted Proteins database (TPdb; http://www.targetedproteinsdb.com).

\section{Roles of the UPS in muscle wasting}

Skeletal muscle wasting, or atrophy, is characterized by a reduction in muscle mass due to an imbalance between protein synthesis and degradation, resulting in a loss of net protein content in the myofibers (see reviews cited in [1] for more information). Even though there is clear evidence that a reduction in protein synthesis participates in this process, there is now a large body of experiments showing that a central mechanism in muscle wasting is increased intracellular proteolysis, due in particular (but not exclusively [2]) to the activation of the ubiquitin proteasome system (UPS) [3,4].

Muscle wasting occurs in a variety of physiological or pathological circumstances, including inactivity or muscle disuse, fasting and many diseases such as cancer, renal failure or trauma [5]. As skeletal muscle is the major protein reservoir of the body, muscle wasting has beneficial effects in its initial stage since it provides the organism with an ample pool of free amino acids that can be reused for energy production or protein synthesis in vital organs [6]. However, in a variety of pathologies such as cancer, sepsis and diabetes, this catabolic state is maintained over a long period of time and can become life-threatening; this condition is often referred to as cachexia [7].

The aim of this review is to provide an overview on the role of the UPS in muscle wasting. For the sake of space, only the mechanisms presently thought to be common to most types of muscle wasting are described, and the reader 
is invited to refer to numerous recent reviews for more detailed information on specific topics $[1,5,6,8-11]$. It should be noted that most of the results described in this review were obtained with animal models of severe muscle wasting. Therefore, extrapolation to humans of the mechanisms presented below should be treated with caution.

\section{UPS components involved in muscle wasting}

Initial studies, mostly performed using muscles isolated from animals subjected to induced muscle wasting, led to the conclusion in the early 1990s that increased ATPdependent proteolysis accounted for a large part of muscle protein loss in several muscle wasting models [12]. After the subsequent recognition that the UPS (initially discovered and dissected in rabbit reticulocyte lysate [13-15]) was responsible for ATP-dependent proteolysis in mammalian cells [16], and the demonstration that its general inhibition by proteasome inhibitors reduces the accelerated proteolysis in atrophying muscles [17], several groups turned to the analysis of expression of individual UPS components in different experimental models of muscle wasting (see Table 1).
In general, the UPS functions in two distinct steps to degrade intracellular proteins. First, the substrate protein is labeled by covalent linkage of polyubiquitin (polyUb) chain(s) to one or several lysine residue(s) by the action of an enzymatic cascade involving three types of factors, referred to as E1, E2s and E3s [18]. In this reaction, the E3s act as substrate recognition factors and are thus the main determinants of the specificity of the UPS [19]. Consequently, their number is very high, with a rough estimation of several hundred E3s present in the genome, depending on the organism [20]. The second step in protein degradation by the UPS is the degradation of the polyubiquitylated substrate by the $26 \mathrm{~S}$ proteasome, a large compartmentalized protease comprising the $20 \mathrm{~S}$ proteasome, which contains the proteolytic active sites in its internal catalytic chamber, and the $19 \mathrm{~S}$ regulatory complex, which is essential for degradation of ubiquitylated proteins $[21,22]$.

A common theme in most models of muscle wasting is a significant increase at the mRNA level of many components of the UPS. These include ubiquitin (Ub), E2s, proteasome subunits (20S and 19S), deubiquitylating enzymes and certain E3s [6,8,23-25]. The accepted interpretation is that this upregulation of UPS mRNAs partici-

Table I: Main conditions used to induce muscle wasting in animals (mice and rats) and the variation of key components involved in UPS activation. Please note that the models in this table were generated only for the experiments: muscle wasting was induced in normal animals by various treatments and the molecular mechanisms subsequently analyzed.

\begin{tabular}{|c|c|c|c|c|c|c|}
\hline \multirow{2}{*}{$\begin{array}{l}\text { Main models of } \\
\text { muscle wasting }\end{array}$} & \multicolumn{6}{|c|}{ Variation of key components involved in UPS activation } \\
\hline & UPS mRNAs & $\begin{array}{l}\text { N-end rule } \\
\text { pathway }\end{array}$ & NFKB activity & MuRF-I & MAFbx & $\begin{array}{l}\text { Selected } \\
\text { reference }\end{array}$ \\
\hline Cancer cachexia & & & & & & {$[84,100]$} \\
\hline Sepsis & 仓 & 仓 & 仓 & 仓 & $\hat{\imath}$ & {$[101,102]$} \\
\hline & 仓 & 仓 & 仓 & 仓 & 仓 & \\
\hline $\begin{array}{l}\text { Hindlimb } \\
\text { suspension }\end{array}$ & 仓े & 仓े & 仓े & 仓े & 仓े & {$[89,103]$} \\
\hline Denervation & & ? & & & & {$[17,31,104]$} \\
\hline Hyperthyroidism & 仓 & ? & 仓 & 仓 & 仓 & {$[17,105]$} \\
\hline Burn injuries & 仓 & & 仓े & 仓 & 仓 & {$[106,107]$} \\
\hline Cirrhosis & 仓 & $\begin{array}{l}\text { 仓 } \\
?\end{array}$ & $\widehat{\imath}$ & 仓 & 仓े & {$[108,109]$} \\
\hline Starvation & 仓 & & 仓 & 仓े & $\hat{\imath}$ & {$[110,111]$} \\
\hline Diabetes & 仓े & 仓 & 仓 & 仓 & $\hat{\imath}$ & {$[56,105,112]$} \\
\hline Uremia & 仓 & $\begin{array}{l}\text { 仓े } \\
?\end{array}$ & 仓 & 仓 & $\hat{\mathbf{v}}$ & {$[37,113]$} \\
\hline & 仓 & & 仓 & 仓 & 仓 & \\
\hline
\end{tabular}

仓 : upregulation; ?: not determined or unclear. 
pates in the overall activation of the UPS observed during muscle wasting, in line with the fact that an increase in (i) the rate of Ub conjugation to proteins, (ii) the intracellular level of ubiquitylated proteins and (iii) proteasome activity has been described in most muscle wasting conditions [6,8]; see also Table 1]. However, it should be noted that, despite the upregulation of their corresponding mRNA, the level of many UPS proteins does not appear significantly altered during muscle wasting. The reasons for this discrepancy are unclear, but an interesting hypothesis is that the increased synthesis of these proteins is compensated by an accelerated turnover under the conditions analyzed.

The first specific UPS pathway described to be involved in muscle wasting was the ' $\mathrm{N}$-end rule' pathway ([26,27]; see also section on Substrates of the UPS during muscle wasting), which rapidly degrades proteins with destabilizing N-terminal residues (see [28] for review). In mammals, this pathway involves a specific E2 (E2-14K) and several E3 isoforms [29], among which E3 $\alpha$-II (also known as UBR2) is increased in skeletal muscle during cachexia [27]. The specific inhibition of this E3 reduces the rate of ubiquitylation of soluble or model proteins in muscle extracts from tumor-bearing or septic rats, as well as in C2C12 cell extracts $[26,27]$.

Transcriptome analyses showed that two other types of E3 or E3 components are upregulated in most muscle wasting models. These are the F-box component MAFbx (also known as Atrogin-1) of the SCFMAFbx E3 and the MuRF family of RING finger E3s [30,31], which interact with and possibly ubiquitylate a variety of myofibrillar proteins [32,33]. Expression of MAFbx and MuRF-1 mRNAs increases dramatically in catabolic states and mice deficient in either of them are partially resistant to denervation atrophy [31]. Therefore, MAFbx and MuRF-1 play a crucial role in the loss of muscle proteins and their mRNAs are now considered to be specific atrophic markers.

\section{Substrates of the UPS during muscle wasting}

The major proteins in muscle are the myofibrillar components; however, although monomeric actin and myosin can be degraded by the UPS, it is assumed that this is not the case in intact myofibers since specific interactions between these proteins protects them from degradation by this system [34]. Thus, an early step in muscle wasting must be the dissociation or at least the destabilization of the myofibrils, a process in which non-UPS proteases shown to be involved in muscle wasting (such as calpains [35,36], caspase 3 [37] or cathepsin L [38]) probably play a key role. Though the early involvement of non-UPS proteases in the destabilization of myofibrils has not been formally demonstrated, this hypothesis is likely since it helps to explain the observed role of the UPS N-end rule pathway in muscle wasting. Indeed, this pathway requires the substrate to expose a destabilizing $\mathrm{N}$-terminal residue [28], a feature that is rare for native cellular proteins; however, polypeptides with a destabilizing $\mathrm{N}$-terminal residue can be produced by proteolytic cleavage of native proteins by cellular proteases [39].

Another mechanism that controls myofibril organization involves the sarcomeric scaffold protein titin, which possesses a protein kinase domain essential for sarcomere integrity $[40,41]$. Interestingly, the activity of this domain is modulated by mechanical strain [42], allowing titin to convert tension forces into molecular signals. This function controls both the intracellular level and localization of the RING finger E3 MuRF-2 (a protein closely related to MuRF-1), which is associated with titin in the sarcomeres through interaction with the UBD (Ub binding domain [43])-containing proteins Nbr1 and p62, and is translocated to the nucleus upon muscle inactivity [44]. Nuclear localization of MuRF-2 in turn leads to nuclear exclusion of SRF (serum response factor) [44], a transcription factor central to muscle response to hypertrophic stimuli. Thus, titin appears to be an important relay in the control of muscle disuse atrophy, since it is able to couple mechanical inactivity with muscle wasting by triggering macromolecular rearrangements of sarcomeres and altering muscle transcriptional programs. The importance of the titinNbr1-p62-MuRF-2 interaction is underlined by a human mutation disrupting binding of Nbr1 to titin, which causes an autosomal dominant muscle disease called heredity myopathy with early respiratory failure (HMERF) [44]. In muscle biopsies of HMERF patients, the structure of sarcomeres is altered and the localization of Nbr1, p62 and MuRF-2 is abnormal [44].

In addition to these mechanisms, the crucial roles of MAFbx and MuRF-1 during atrophy indicate that these E3s target key negative regulators of muscle wasting for degradation. However, only a few actual or potential substrates have been identified for these E3s and the relevance of these substrates for muscle wasting remains unclear (see Signaling pathways involved in muscle wasting).

\section{Signaling pathways involved in muscle wasting}

Glucocorticoids are known to be important mediators of muscle wasting in various catabolic conditions [5]; indeed, dexamethasone triggers upregulation of various UPS components [45]. However, the underlying mechanisms of glucocorticoid signaling in muscle wasting are not yet fully understood [23].

Presently, two families of transcription factors have been clearly identified as crucial positive mediators of muscle wasting: the FoxO (forkhead box $\mathrm{O}$ ) transcription factors 
and NFאB [9]. Of note, these factors are involved in the control of expression of the E3s MuRF-1 and MAFbx [46$48]$.

PI3K is activated by anabolic signals triggered by insulin or IGF-1 upon binding to their receptors, which in turn activates Akt [49] (a kinase central to muscle hypertrophy), as shown in transgenic mice in which an active form of Akt can be inducibly expressed in adult skeletal muscle [50]. Besides its function in stimulating protein synthesis via mTOR and GSK3 [9], a crucial role for activated Akt is to phosphorylate FoxO $[46,47,51]$, leading to transcriptional inactivation of FoxO due to its release from DNA and 14-3-3 protein-mediated cytoplasmic sequestration (see [52] for review), and to subsequent inhibition of muscle wasting. In many systemic diseases, including diabetes, cancer and renal failure, low circulating levels of insulin and IGF-1, or resistance to their action, contribute to muscle wasting via inactivation of the PI3K/Akt pathway, which leads to the subsequent dephosphorylation and activation of FoxO [53-56]. Interestingly, it has recently been shown that myostatin treatment can also trigger the same effect in mice [57]. Myostatin is a TGF $\beta$ super-family member that acts as a negative regulator of muscle growth and is implicated in several forms of muscle wasting [58]. Myostatin signaling reverses the IGF-1/ PI3K/Akt pathway by inhibiting phosphorylation of Akt, leading to activation of FoxO and thereby activation of E2-14K, MuRF-1 and MAFbx [57].

In many disease states, stress or inflammatory cytokines such as tumor necrosis factor alpha (TNF $\alpha)$ are produced [59]. Stimulation of their receptors activates the IKK kinase, which in turn phosphorylates the NFKB inhibitor I $\mathrm{B} \alpha$, promoting its degradation by the UPS. This leads to the release of $\mathrm{NFKB}$, which migrates to the nucleus to activate its target genes [60]. Demonstration of a role for this pathway in muscle wasting comes from many observations, including the fact that constitutive activation of IKK in transgenic mice triggered both a decrease in total muscle mass and an increase in atrophy markers, which were reversed by expression of IкB $\alpha$ [48]. A further observation supporting a role for this pathway in muscle wasting is that direct inhibition of NFKB inhibited cachexia in a mouse tumor model [61]. In addition, in cancer cachexia, tumor-derived factors such as proteolysis-inducing factor (PIF) $[62,63]$, or elevated levels of endogenous factors such as angiotensin I and II, are thought to contribute to muscle atrophy through activation of the NFKB pathway. Supporting evidence comes from the fact that these factors induce increased expression of UPS components (proteasome subunits, E2-14K) and stimulate protein degradation in murine $\mathrm{C} 2 \mathrm{C} 12$ myotubes in a manner requiring I $\mathrm{B} \alpha$ degradation and nuclear translocation of $\mathrm{NF \kappa B}$ $[64,65]$. Interestingly, although activation of NFkB is also required for muscle disuse atrophy, the NFkB family members that are activated appear distinct from those activated by the TNF $\alpha$ pathway $[1,66]$.

$\mathrm{NF \kappa B}$ and FoxO are thus key players in the activation of muscle wasting. Interestingly, their known targets include MuRF-1 and MAFbx for FoxO [46,47], and MuRF-1 for NFkB [48]. However, as mentioned in the section on Substrates of the UPS during muscle wasting, the key substrates of these E3s in muscle wasting are unclear. Nevertheless, one hypothesis is that induction of MuRF-1 activity is important for the destabilization of myofibrillar complexes required for the subsequent degradation of myofibrillar proteins. Indeed, the interaction between MuRF-1 and titin has been shown to be important for sarcomere stability [67]. Furthermore, in yeast two-hybrid screens, MuRF-1 interacts with several myofibrillar proteins (titin, nebulin, the nebulin-related protein NRAP, troponin-I, troponin- $\mathrm{T}$, myosin light chain 2, myotilin and T-cap) [33], suggesting that this E3 can mediate their ubiquitylation and degradation in muscle. MuRF-1-mediated ubiquitylation and degradation, however, has only been proven for troponin I [68] and possibly for myosin light chain 2 [33] in cardiac tissue. The lack of clear results regarding the role of MuRF-1 in the degradation of its other interactors could be due to its functional redundancy with MuRF-2.

The known targets of MAFbx (calcineurin A [32] and MyoD [69])) are unlikely to be crucial for muscle wasting, since calcineurin A does not appear to affect myofiber size [70] and MyoD is involved in muscle cell differentiation. The key substrates of MAFbx in muscle wasting thus remain to be identified. Interestingly, however, TNF $\alpha /$ $\mathrm{NFKB}$ signaling reduces both the level of MyoD mRNA [48] and the stability of MyoD [71], and forced expression of MAFbx inhibits the formation of myotubes in an in vitro model of muscle differentiation [69]. Thus, the role of MAFbx in the down-regulation of MyoD could in fact be indirectly important for muscle wasting, since the inactivation of MyoD functions necessary for the differentiation of muscle satellite cells possibly inhibits muscle regeneration.

\section{Concluding remarks}

In this brief overview, we have summarized the role of the UPS as an essential mediator of muscle wasting. Even though much remains to be understood before a complete picture of the intricate mechanisms controlling muscle atrophy can emerge, our knowledge to date already suffices to demonstrate that the UPS is an attractive potential target for therapeutic treatments aimed at slowing down muscle atrophy when it becomes harmful to the organism [5]. The different levels of possible therapeutic 
intervention are discussed in the section on Potential targets and drugs for muscle wasting therapy.

\section{Analysis of muscle wasting: models, knockouts and assays \\ Main models of muscle wasting}

Muscle wasting occurs when the overall rate of protein proteolysis exceeds in a sustained manner that of protein synthesis in muscle. Since a variety of physiological and pathological conditions can influence the equilibrium between these two processes, several animal (mostly murine) models have been developed (see Table 1) to analyze the mechanisms of muscle mass loss in these different conditions [72]. For example, cancer, sepsis and cirrhosis are inflammatory conditions that induce muscle wasting through the inhibition of anabolic pathways and the secretion of cytokines (IL1, TNF $\alpha$ ) or catabolic factors (PIF), while hindlimb suspension, denervation and sarcopenia are conditions in which disuse atrophy is present. In most models, despite variations in the extent of involvement of the UPS relative to other processes (including other proteolytic systems), activation of UPS-dependent proteolysis transpires to be a crucial event [6]. Moreover, as described in the section on Roles of the UPS in muscle wasting, biochemical and molecular analyses have determined that a convergent mechanism for this activation is the upregulation of crucial ubiquitylation pathways involving the N-End rule E3s as well as the E3s SCFMAFbx and MuRF-1 [73], even though the substrates of these enzymes during muscle wasting remain unclear at present.

\section{Knockouts of components involved in muscle wasting}

Several mouse strains deficient in components involved in muscle wasting have been constructed and tested for their protection against muscle atrophy (see Table 2). Manipulation of the N-end rule pathway, by deletion of the genes encoding either E2-14K or the E3 UBR1 [74,75], did not significantly impair muscle wasting, probably because of the functional redundancy between the many components of this pathway [29] and/or because this pathway is only responsible for the breakdown of soluble muscle proteins. By contrast, mice in which either the MAFbx- or MuRF-1-encoding gene has been deleted become partially resistant to atrophy induced by denervation, highlighting the crucial role of these two E3s in the process of muscle wasting. Finally, mice with altered control of the NFkB pathway demonstrate the key function of this pathway in inducing muscle atrophy.

\section{Assays for analysis of muscle wasting}

In addition to the measurement of muscle mass after isolation of specific muscles from model animals, protein breakdown in incubated muscle is often quantified by the release of tyrosine, which is neither synthesized nor metabolized in skeletal muscle [76]. Furthermore, release of 3-methylhistidine, a modified amino acid found in actin and myosin that can be neither reincorporated into protein nor metabolized, can also be measured $[77,78]$.

\section{Potential targets and drugs for muscle wasting therapy}

As summarized in the section on Roles of the UPS in muscle wasting and figure 1, there are several levels of possible therapeutic intervention to limit muscle wasting. The first level is to modulate the expression or activity of circulating factors that either promote muscle hypertrophy (such as insulin or IGF-1) [79], inhibit muscle growth (such as myostatin) [58], or induce the UPS and/or NFKB (such as the cytokines TNF $\alpha$ or IL6, the secreted glycoprotein PIF, or oxidative stress) [5]. The second level involves targeting intracellular effectors of muscle wasting, such as the transcription factor FoxO or the NFKB pathway. Finally, a third level of possible therapeutic intervention is direct inhibition of the UPS.

As the exploration of these different possibilities is currently underway, only partial and limited information is presently available. To date, most compounds presently tested on animal models or in clinic for their ability to limit muscle wasting are commercially available chemicals, and many of them have been identified through empirical approaches aimed at treating cachexia [80]. Among those, EPA (eicosapentaenoic acid), which has

Table 2: Mouse models genetically modified for proteins involved in muscle wasting

\begin{tabular}{lll}
\hline Genetically modified mice & Effect on muscle (muscle wasting condition tested) & Selected references \\
\hline KO MuRF-I & Partial protection against atrophy (denervation) & {$[3 I]$} \\
KO Atrogin-I/MAFbx & Partial protection against atrophy (denervation) & {$[3 I]$} \\
KO E2-I 4K & Non-resistant to atrophy (fasting) & {$[74, I I 4]$} \\
KO UBRI & Decreased muscle mass & {$[75]$} \\
Mdx & Model for Duchenne muscular dystrophy: in these mice blockade of NFKB partially & {$[I I 5]$} \\
KI FoxO & restores muscle function & {$[I I 6]$} \\
MIKK constitutively active IKK & FoxO overexpressing mice: negative effect on skeletal muscle mass & {$[48]$} \\
MISR non-degradable IKB & Severe atrophy resembling cachexia & {$[48]$}
\end{tabular}




\section{Possible targets}

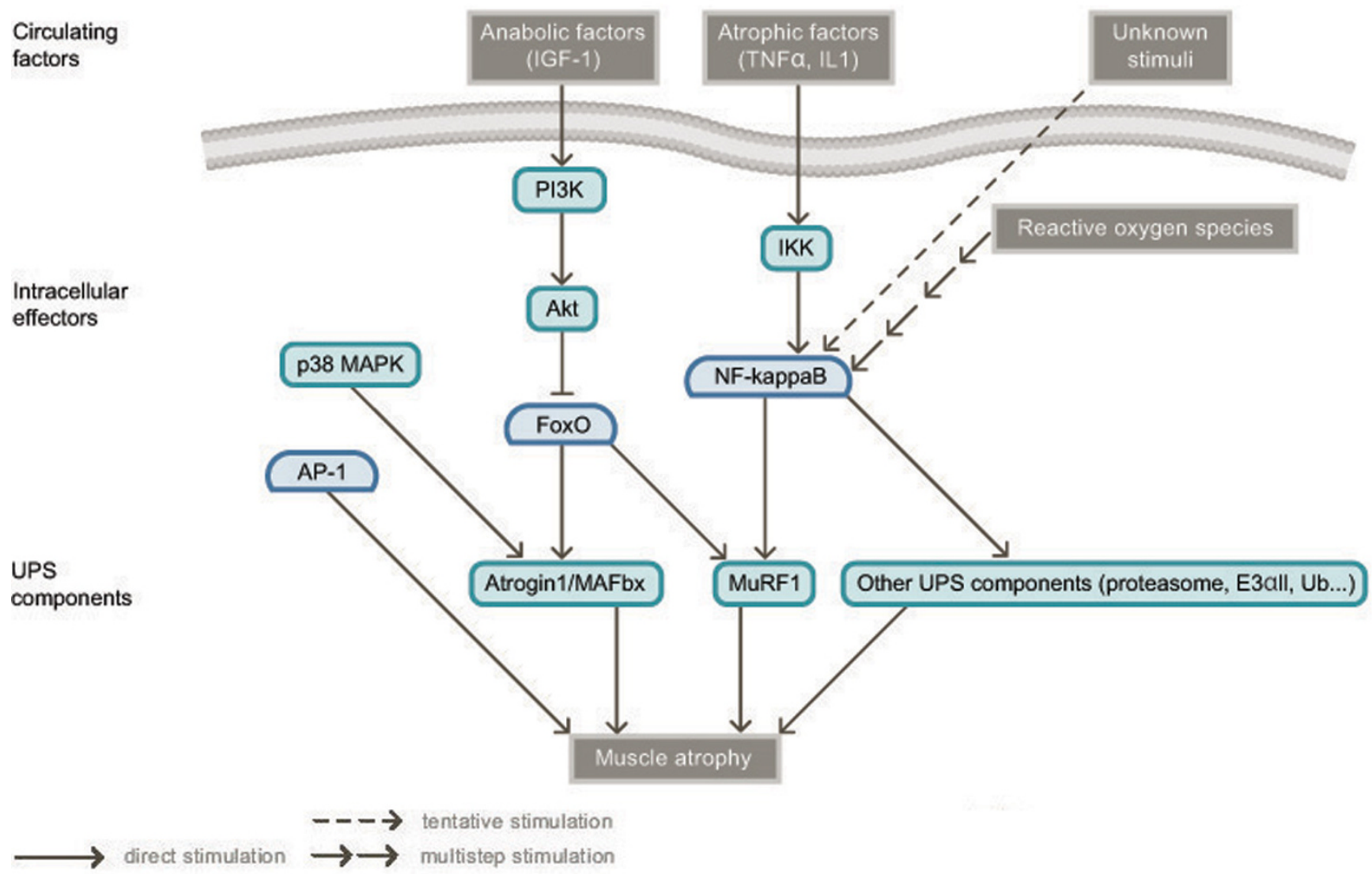

Figure I

Potential therapeutic targets in muscle wasting. The figure illustrates possible therapeutic targets in muscle wasting, including circulating factors, intracellular effectors and components of the ubiquitin proteasome system (UPS).

been shown to down-regulate the increase in UPS activity seen in cachexia [81], and thalidomide, which inhibits production of TNF $\alpha$ by increasing the rate of degradation of its mRNA [82], have demonstrated a degree of efficacy $[80,83,84]$.

Other inhibitors of TNF $\alpha$ expression represent attractive therapeutic strategies against cachexia. Although the xanthine derivative pentoxifylline [85] can suppress cachexiainduced activation of the UPS in rats [86], its effects in clinical trials have been uncertain [87]. However, another xanthine derivative, torbafylline (HWA 448), showed encouraging properties in a study on animal models, since it appeared more potent in preventing muscle wasting than pentoxifylline [88].

Several studies have analyzed the potential effect on muscle wasting of beta2 agonists such as clenbuterol [89], fenoterol [90] and formoterol [91]. These anabolic drugs appear effective against atrophy, mostly by counteracting activation of the UPS. Though the potential use of clen- buterol to treat muscle wasting appears limited since it has deleterious side effects in humans (particularly tachycardia and hypokalemia [92]), formoterol is already in use in human therapy (against chronic obstructive pulmonary disease) and thus appears to be an interesting candidate for human trials.

Due to the prominent role of NFKB in cachexia, drugs inhibiting the activation of this transcription factor have also been tested in various settings. Active molecules include HMB ( $\beta$-hydroxy- $\beta$-methylbutyrate, a leucine metabolite) [80], ibuprofen [80] and resveratrol, the latter of which appears to be the most promising drug candidate for clinical use against muscle wasting $[84,93]$.

Since the proteasome is a central component in muscle wasting, it represents an attractive target despite its pleiotropic functions. Indeed, many studies in animals have demonstrated that proteasome inhibitors are efficient at blocking muscle wasting $[6,94]$; however, no report on their effect on muscle wasting in humans has yet been 
published. The recent success of Millennium Pharmaceuticals with the proteasome inhibitor bortezomib (PS-341, Velcade ${ }^{\circledR}$ ) for treatment of multiple myeloma [95] prompted many biotech or pharmaceutical companies to develop new molecules targeting the proteasome, including Nereus (NPI-0052), Proteolix (PR-171), Santhera and ALSTDF. Although muscle wasting is not the primary interest of these companies, these efforts could help to produce new compounds with interesting anti-atrophying properties in the future.

Finally, it is important to highlight that, when possible, muscular exercise is an efficient method of limiting disuse atrophy since, as shown by analyses in humans, it negatively influences the signaling pathways activated in muscle wasting, leading in particular to down-regulation of the E3s MAFbx and MuRF-1 [96].

\section{New frontiers in drug discovery}

Knowledge of the molecular mechanisms responsible for muscle wasting, as summarized in figure 1, has been acquired relatively recently and much remains to be understood before a more accurate description of this process is obtained. For example, the contribution of the AP-1 transcription factors to muscle wasting [97], or of the p38 MAP kinase to activation of MAFbx [98], remains to be clarified. In addition, future studies will certainly characterize novel factors involved in atrophy and provide a better evaluation of the therapeutic potential of activating or inhibiting the many pathways controlling muscle wasting. Nevertheless, as several levels of therapeutic intervention have been identified and drug candidates are currently being tested, it is most likely that efficient drugs against muscle wasting will be soon available. However, the many problems of bioavailability and of specific targeting of muscle tissues remain to be solved in most cases.

A clear limitation in the current attempts to reduce muscle wasting is that the targeted molecules are not muscle-specific; meaning that alteration of their expression or activity is bound to induce side effects that could worsen the clinical status of the patient. A combination of drugs displaying synergistic effects, as shown recently for pentoxifylline and formoterol [55], could help to improve treatment since this strategy could allow use of sub-therapeutic doses of each drug, decreasing the possibility of harmful side effects.

Clearly, an alternative goal is to develop compounds that will target specific factors that are key for muscle wasting and that have no general functions outside muscle. In this respect, the E3s specifically induced during muscle wasting, such as the N-end rule E3s or MuRF-1, are extremely attractive candidates. However, as illustrated in the Mdm2/p53 pathway (see [99] for review), the best approach to obtain specific and efficient inhibitors of E3s is to aim to disrupt the interaction of the $\mathrm{E} 3$ with its substrate(s). This requires substantial information on the nature of the relevant substrates of the $\mathrm{E} 3$ and on the structure of the E3-substrate pair to be targeted. As such information is presently not available for the E3s involved in muscle wasting, important goals for the future are to identify their substrates and to define the structural basis of their interaction with these substrates.

\section{List of abbreviations}

Akt $=$ serine/threonine protein kinase $; \mathrm{FoxO}=$ forkhead box O; GSK3 = glycogen synthase kinase 3; IGF-1 = insulin-like growth factor 1 ; $\mathrm{KI}=$ knockin; $\mathrm{KO}=$ knockout; MAFbx = muscle atrophy F-box; MAP kinase = mitogenactivated protein kinase; $\mathrm{mTOR}=$ mammalian target of rapamycin; MuRF1 = muscle RING finger 1 ; $\mathrm{NF \kappa B}=$ nuclear factor kappa B; PI3K = phosphatidylinositol 3kinase; PIF = proteolysis inducing factor; $\mathrm{SCF}=\mathrm{SKP} 1-$ cul lin-F-box protein; $\mathrm{SRF}=$ serum response factor; $\mathrm{TGF} \beta=$ transforming growth factor beta; TNF $\alpha=$ tumor necrosis factor alpha; Ub = ubiquitin; UBD = ubiquitin binding domain; UPS = ubiquitin proteasome system.

\section{Competing interests}

The authors declare that they have no competing interests.

\section{Acknowledgements}

We thank Dr. S.H. Lecker for critical reading of this manuscript. We also thank the members of our group for their help and suggestions. Our work on the roles of the UPS in muscle was supported by grants from the Association Française contre les Myopathies (AFM). DN and CD were supported by an AFM and a FRM (Fondation pour la Recherche Médicale) fellowship, respectively.

This article has been published as part of BMC Biochemistry Volume 8 Supplement I, 2007: Ubiquitin-Proteasome System in Disease Part I. The full contents of the supplement are available online at http://www.biomedcen tral.com/|47|-209|/8?issue=SI.

\section{References}

I. Kandarian SC, Jackman RW: Intracellular signaling during skeletal muscle atrophy. Muscle Nerve 2006, 33:155-165.

2. Bechet D, Tassa A, Taillandier D, Combaret L, Attaix D: Lysosomal proteolysis in skeletal muscle. Int J Biochem Cell Biol 2005, 37:2098-2। I4.

3. Mitch WE, Goldberg AL: Mechanisms of muscle wasting. The role of the ubiquitin-proteasome pathway. N Engl] Med I996, 335: 1897-1905.

4. Attaix D, Aurousseau E, Combaret L, Kee A, Larbaud D, Ralliere C, Souweine B, Taillandier D, Tilignac T: Ubiquitin-proteasomedependent proteolysis in skeletal muscle. Reprod Nutr Dev 1998, 38:153-165.

5. Tisdale M]: The ubiquitin-proteasome pathway as a therapeutic target for muscle wasting. J Support Oncol 2005, 3:209-2I7.

6. Attaix D, Ventadour S, Codran A, Bechet D, Taillandier D, Combaret $\mathrm{L}$ : The ubiquitin-proteasome system and skeletal muscle wasting. Essays Biochem 2005, 41:173-186.

7. Morley JE, Thomas DR, Wilson MM: Cachexia: pathophysiology and clinical relevance. Am J Clin Nutr 2006, 83:735-743.

8. Wing SS: Control of ubiquitination in skeletal muscle wasting. Int J Biochem Cell Biol 2005, 37:2075-2087. 
9. Glass DJ: Skeletal muscle hypertrophy and atrophy signaling pathways. Int J Biochem Cell Biol 2005, 37: 1974- 1984.

10. Lecker SH, Goldberg AL, Mitch WE: Protein degradation by the ubiquitin-proteasome pathway in normal and disease States. J Am Soc Nephrol 2006, 17:1807-1819.

II. Stein TP, Bolster DR: Insights into muscle atrophy and recovery pathway based on genetic models. Curr Opin Clin Nutr Metab Care 2006, 9:395-402.

12. Attaix D, Taillandier D, Temparis S, Larbaud D, Aurousseau E, Combaret L, Voisin L: Regulation of ATP-ubiquitin-dependent proteolysis in muscle wasting. Reprod Nutr Dev 1994, 34:583-597.

13. Etlinger J, Goldberg AL: A soluble, ATP-dependent proteolytic system responsible for the degradation of abnormal proteins in reticulocytes. Proc Natl Acad Sci USA 1977, 74:54-58.

14. Ciechanover A, Elias S, Heller H, Ferber S, Hershko A: Characterization of the heat-stable polypeptide of the ATP-dependent proteolytic system from reticulocytes. I Biol Chem 1980, 255:7525-7528.

15. Ganoth D, Leshinsky E, Eytan E, Hershko A: A multicomponent system that degrades proteins conjugated to ubiquitin. Resolution of factors and evidence for ATP-dependent complex formation. J Biol Chem 1988, 263:124I2-12419.

16. Ciechanover A: Proteolysis: from the lysosome to ubiquitin and the proteasome. Nat Rev Mol Cell Biol 2005, 6:79-87.

17. Tawa NE, Odessey R, Goldberg AL: Inhibitors of the proteasome reduce the accelerated proteolysis in atrophying rat skeleta muscles. J Clin Invest 1997, 100:197-203.

18. Hershko A, Ciechanover A: The ubiquitin system. Annu Rev Biochem 1998, 67:425-479.

19. Schulman BA, Carrano AC, Jeffrey PD, Bowen Z, Kinnucan ER, Finnin MS, Elledge S, Harper JW, Pagano M, Pavletich NP: Insights into SCF ubiquitin ligases from the structure of the SkpI-Skp2 complex. Nature 2000, 408:38I-386.

20. Robinson PA: Ubiquitin-protein ligases - novel therapeutic targets? Curr Protein Pept Sci 2004, 5: 163-176.

21. Voges D, Zwickl P, Baumeister W: The 265 proteasome: a molecular machine designed for controlled proteolysis. Annu Rev Biochem 1999, 68:1015-1068.

22. Rechsteiner M, Hill CP: Mobilizing the proteolytic machine: cell biological roles of proteasome activators and inhibitors. Trends Cell Biol 2005, 15:27-33.

23. Price SR: Increased transcription of ubiquitin-proteasome system components: molecular responses associated with muscle atrophy. Int J Biochem Cell Biol 2003, 35:617-628.

24. Lecker $\mathrm{SH}$ : Ubiquitin-protein ligases in muscle wasting: multiple parallel pathways? Curr Opin Clin Nutr Metab Care 2003, 6:27I-275.

25. Combaret L, Adegoke OA, Bedard N, Baracos V, Attaix D, Wing SS: USP I 9 is a ubiquitin-specific protease regulated in rat skeletal muscle during catabolic states. Am J Physiol Endocrinol Metab 2005, 288:E693-700

26. Solomon V, Baracos V, Sarraf $P$, Goldberg AL: Rates of ubiquitin conjugation increase when muscles atrophy, largely through activation of the $\mathbf{N}$-end rule pathway. Proc Natl Acad Sci U S A 1998, 95:12602-12607.

27. Kwak KS, Zhou X, Solomon V, Baracos VE, Davis J, Bannon AW, Boyle WJ, Lacey DL, Han HQ: Regulation of protein catabolism by muscle-specific and cytokine-inducible ubiquitin ligase E3\{alpha\}-II during cancer cachexia. Cancer Res 2004, 64:8193-8198.

28. Varshavsky A, Turner G, Du F, Xie Y: The ubiquitin system and the $\mathbf{N}$-end rule pathway. Biol Chem 2000, 381:779-789.

29. Tasaki T, Mulder LC, Iwamatsu A, Lee MJ, Davydov IV, Varshavsky A, Muesing M, Kwon YT: A family of mammalian E3 ubiquitin ligases that contain the UBR Box Motif and recognize Ndegrons. Mol Cell Biol 2005, 25:7।20-7।36.

30. Gomes MD, Lecker SH, Jagoe RT, Navon A, Goldberg AL: AtroginI, a muscle-specific F-box protein highly expressed during muscle atrophy. Proc Natl Acad Sci U S A 200I, 98: I4440-I 4445

31. Bodine SC, Latres E, Baumhueter S, Lai VK, Nunez L, Clarke BA, Poueymirou WT, Panaro FJ, Na E, Dharmarajan K, Pan ZQ, Valenzuela DM, DeChiara TM, Stitt TN, Yancopoulos GD, Glass DJ: Identification of ubiquitin ligases required for skeletal muscle atrophy. Science 2001, 294: 1704-1708.

32. Li HH, Kedar V, Zhang C, McDonough H, Arya R, Wang DZ, Patterson C: Atrogin-I/muscle atrophy F-box inhibits calcineurin- dependent cardiac hypertrophy by participating in an SCF ubiquitin ligase complex. J Clin Invest 2004, I 1 4: 1058- I07|

33. Witt SH, Granzier H, Witt CC, Labeit S: MURF-I and MURF-2 target a specific subset of myofibrillar proteins redundantly: towards understanding MURF-dependent muscle ubiquitination. J Mol Biol 2005, 350:713-722.

34. Solomon V, Goldberg AL: Importance of the ATP-ubiquitinproteasome pathway in the degradation of soluble and myofibrillar proteins in rabbit muscle extracts. J Biol Chem 1996, 27 I:26690-26697.

35. Bartoli M, Richard I: Calpains in muscle wasting. Int J Biochem Cell Biol 2005, 37:21115-2133.

36. Costelli P, Reffo P, Penna F, Autelli R, Bonelli G, Baccino FM: Ca(2+)dependent proteolysis in muscle wasting. Int J Biochem Cell Biol 2005, 37:2134-2/46.

37. Du J, Wang X, Miereles C, Bailey JL, Debigare R, Zheng B, Price SR, Mitch WE: Activation of caspase-3 is an initial step triggering accelerated muscle proteolysis in catabolic conditions. J Clin Invest 2004, I 13:1 I5-123.

38. Deval C, Mordier S, Obled C, Bechet D, Combaret L, Attaix D, Ferrara $M$ : Identification of cathepsin $L$ as a differentially expressed message associated with skeletal muscle wasting. Biochem / 200I, 360: 143-I50.

39. Rao H, Uhlmann F, Nasmyth K, Varshavsky A: Degradation of a cohesin subunit by the $\mathrm{N}$-end rule pathway is essential for chromosome stability. Nature 200I, 4 10:955-959.

40. Gotthardt M, Hammer RE, Hubner N, Monti J, Witt CC, McNabb M, Richardson JA, Granzier H, Labeit S, Herz J: Conditional expression of mutant $\mathrm{M}$-line titins results in cardiomyopathy with altered sarcomere structure. J Biol Chem 2003, 278:6059-6065.

4I. Miller G, Musa H, Gautel M, Peckham M: A targeted deletion of the C-terminal end of titin, including the titin kinase domain, impairs myofibrillogenesis. J Cell Sci 2003, I I 6:48I I-48। 9.

42. Grater F, Shen J, Jiang H, Gautel M, Grubmuller H: Mechanically induced titin kinase activation studied by force-probe molecular dynamics simulations. Biophys J 2005, 88:790-804.

43. Hicke L, Schubert HL, Hill CP: Ubiquitin-binding domains. Nat Rev Mol Cell Biol 2005, 6:610-62I.

44. Lange S, Xiang F, Yakovenko A, Vihola A, Hackman P, Rostkova E, Kristensen J. Brandmeier B, Franzen G, Hedberg B, Gunnarsson LG, Hughes SM, Marchand S, Sejersen T, Richard I, Edstrom L, Ehler E, Udd B, Gautel M: The kinase domain of titin controls muscle gene expression and protein turnover. Science 2005, 308:1599-1603

45. Combaret L, Taillandier D, Dardevet D, Bechet D, Ralliere C, Claustre A, Grizard J, Attaix D: Glucocorticoids regulate mRNA levels for subunits of the $19 \mathrm{~S}$ regulatory complex of the $26 \mathrm{~S}$ proteasome in fast-twitch skeletal muscles. Biochem / 2004, 378:239-246

46. Sandri M, Sandri C, Gilbert A, Skurk C, Calabria E, Picard A, Walsh K, Schiaffino S, Lecker SH, Goldberg AL: Foxo transcription factors induce the atrophy-related ubiquitin ligase atrogin-I and cause skeletal muscle atrophy. Cell 2004, I I 7:399-4 I2.

47. Stitt TN, Drujan D, Clarke BA, Panaro F, Timofeyva Y, Kline WO, Gonzalez M, Yancopoulos GD, Glass DJ: The IGF-I/PI3K/Akt pathway prevents expression of muscle atrophy-induced ubiquitin ligases by inhibiting FOXO transcription factors. Mol Cell 2004, I 4:395-403.

48. Cai D, Frantz JD, Tawa NE Jr, Melendez PA, Oh BC, Lidov HG, Hasselgren PO, Frontera WR, Lee J, Glass DJ, Shoelson SE: IKKbeta/ NF-kappaB activation causes severe muscle wasting in mice. Cell 2004, I 1 9:285-298.

49. Rommel C, Bodine SC, Clarke BA, Rossman R, Nunez L, Stitt TN, Yancopoulos GD, Glass DI: Mediation of IGF-I-induced skeletal myotube hypertrophy by PI(3)K/Akt/mTOR and PI(3)K/Akt/ GSK3 pathways. Nat Cell Biol 200I, 3:1009-1013.

50. Lai KM, Gonzalez M, Poueymirou WT, Kline WO, Na E, Zlotchenko E, Stitt TN, Economides AN, Yancopoulos GD, Glass DJ: Conditional activation of akt in adult skeletal muscle induces rapid hypertrophy. Mol Cell Biol 2004, 24:9295-9304.

5I. Sacheck JM, Ohtsuka A, McLary SC, Goldberg AL: IGF-I stimulates muscle growth by suppressing protein breakdown and expression of atrophy-related ubiquitin ligases, atrogin-I and MuRFI. Am J Physiol Endocrinol Metab 2004, 287:E591-60I. 
52. Nader GA: Molecular determinants of skeletal muscle mass: getting the "AKT" together. Int J Biochem Cell Biol 2005, 37:1985-1996.

53. Lee SW, Dai G, Hu Z, Wang X, Du J, Mitch WE: Regulation of muscle protein degradation: coordinated control of apoptotic and ubiquitin-proteasome systems by phosphatidylinositol 3 kinase. J Am Soc Nephrol 2004, I 5: I 537-I 545.

54. Bailey JL, Zheng B, Hu Z, Price SR, Mitch WE: Chronic kidney disease causes defects in signaling through the insulin receptor substrate/phosphatidylinositol 3-kinase/Akt pathway: implications for muscle atrophy. J Am Soc Nephrol 2006 1 7:1388-1394

55. Costelli P, Muscaritoli M, Bossola M, Penna F, Reffo P, Bonetto A, Bus quets S, Bonelli G, Lopez-Soriano FJ, Doglietto GB, Argiles JM, Baccino FM, Rossi Fanelli F: IGF-I is down-regulated in experimental cancer cachexia. Am J Physiol Regul Integr Comp Physiol 2006, 29 I:R674-683.

56. Wang $\mathrm{X}, \mathrm{Hu} \mathrm{Z}, \mathrm{Hu} J$, Du J, Mitch WE: Insulin resistance accelerates muscle protein degradation: activation of the ubiquitinproteasome pathway by defects in muscle cell signaling. Endocrinology 2006, I47:4160-4I68.

57. McFarlane C, Plummer E, Thomas M, Hennebry A, Ashby M, Ling N, Smith $\mathrm{H}$, Sharma M, Kambadur R: Myostatin induces cachexia by activating the ubiquitin proteolytic system through an NF. kappaB-independent, FoxOI-dependent mechanism. J Cell Physiol 2006, 209:50I-5I4.

58. Joulia-Ekaza D, Cabello G: Mysostatin regulation of muscle development: molecular basis, natural mutations, physiopathological aspects. Exp Cell Res 2006, 3 I 2:240 I-24I4.

59. Szewczyk NJ, Jacobson LA: Signal-transduction networks and the regulation of muscle protein degradation. Int J Biochem Cell Biol 2005, 37: |997-201।.

60. Chen ZJ: Ubiquitin signalling in the NF-kappaB pathway. Nat Cell Biol 2005, 7:758-765.

6I. Kawamura I, Morishita R, Tomita N, Lacey E, Aketa M, Tsujimoto S, Manda T, Tomoi M, Kida I, Higaki J, Kaneda Y, Shimomura K, Ogihara $\mathrm{T}$ : Intratumoral injection of oligonucleotides to the NF kappa B binding site inhibits cachexia in a mouse tumor model. Gene Ther 1999, 6:91-97.

62. Lorite MJ, Thompson MG, Drake JL, Carling G, Tisdale MJ: Mechanism of muscle protein degradation induced by a cancer cachectic factor. $\mathrm{Br}$ / Cancer 1998, 78:850-856. (*First description of PIF)

63. Lorite MJ, Smith HJ, Arnold JA, Morris A, Thompson MG, Tisdale MJ Activation of ATP-ubiquitin-dependent proteolysis in skeletal muscle in vivo and murine myoblasts in vitro by a proteolysis-inducing factor (PIF). Br J Cancer 200I, 85:297-302

64. Wyke SM, Tisdale MJ: NF-kappaB mediates proteolysis-inducing factor induced protein degradation and expression of the ubiquitin-proteasome system in skeletal muscle. $\mathrm{Br} /$ Cancer 2005.

65. Russell ST, Wyke SM, Tisdale MJ: Mechanism of induction of muscle protein degradation by angiotensin II. Cell Signal 2006, I 8:1087-1096.

66. Hunter RB, Stevenson E, Koncarevic A, Mitchell-Felton H, Essig DA, Kandarian SC: Activation of an alternative NF-kappaB pathway in skeletal muscle during disuse atrophy. Faseb J 2002 , 1 6:529-538.

67. McElhinny AS, Kakinuma $\mathrm{K}$, Sorimachi $\mathrm{H}$, Labeit $\mathrm{S}$, Gregorio $\mathrm{CC}$ Muscle-specific RING finger-I interacts with titin to regulate sarcomeric M-line and thick filament structure and may have nuclear functions via its interaction with glucocorticoid modulatory element binding protein-I. J Cell Biol 2002, I 57: $125-136$.

68. Kedar V, McDonough H, Arya R, Li HH, Rockman HA, Patterson C Muscle-specific RING finger I is a bona fide ubiquitin ligase that degrades cardiac troponin I. Proc Natl Acad Sci U S A 2004 I0I:|8|35-18|40.

69. Tintignac LA, Lagirand J, Batonnet S, Sirri V, Leibovitch MP, Leibovitch SA: Degradation of MyoD mediated by the SCF (MAFbx) ubiquitin ligase. J Biol Chem 2005, 280:2847-2856.

70. Serrano AL, Murgia M, Pallafacchina G, Calabria E, Coniglio P, Lomo $T$, Schiaffino S: Calcineurin controls nerve activity-dependent specification of slow skeletal muscle fibers but not muscle growth. Proc Natl Acad Sci U S A 2001, 98:13108-13113.
7I. Langen RC, Van Der Velden JL, Schols AM, Kelders MC, Wouters EF, Janssen-Heininger YM: Tumor necrosis factor-alpha inhibits myogenic differentiation through MyoD protein destabilization. Faseb / 2004, I 8:227-237.

72. Lecker SH, Solomon V, Mitch WE, Goldberg AL: Muscle protein breakdown and the critical role of the ubiquitin-proteasome pathway in normal and disease states. I Nutr 1999, I 29:227S-237S

73. Lecker SH, Jagoe RT, Gilbert A, Gomes M, Baracos V, Bailey J, Price SR, Mitch WE, Goldberg AL: Multiple types of skeletal muscle atrophy involve a common program of changes in gene expression. Faseb / 2004, | 8:39-5 |

74. Adegoke OA, Bedard N, Roest HP, Wing SS: Ubiquitin-conjugating enzyme E2( $14 \mathrm{k}) / \mathrm{HR} 6 \mathrm{~B}$ is dispensable for increased protein catabolism in muscle of fasted mice. Am J Physiol Endocrinol Metab 2002, 283:E482-489.

75. Kwon YT, Xia Z, Davydov IV, Lecker SH, Varshavsky A: Construction and analysis of mouse strains lacking the ubiquitin ligase UBRI (E3alpha) of the $\mathbf{N}$-end rule pathway. Mol Cell Biol 200I, 2 I:8007-802I.

76. Fulks RM, Li JB, Goldberg AL: Effects of insulin glucose, and amino acids on protein turnover in rat diaphragm. J Biol Chem 1975, 250:290-298.

77. Huszar G: Developmental changes of the primary structure and histidine methylation in rabbit skeletal muscle myosin. Nat New Biol 1972, 240:260-264.

78. Young VR, Munro HN: Ntau-methylhistidine (3-methylhistidine) and muscle protein turnover: an overview. Fed Proc 1978, 37:2291-2300.

79. Schakman O, Thissen JP: Gene therapy with anabolic growth factors to prevent muscle atrophy. Curr Opin Clin Nutr Metab Care 2006, 9:207-2I3.

80. Tisdale MJ: Clinical anticachexia treatments. Nutr Clin Pract 2006, 21 : |68-174.

8I. Whitehouse AS, Smith HJ, Drake JL, Tisdale MJ: Mechanism of attenuation of skeletal muscle protein catabolism in cancer cachexia by eicosapentaenoic acid. Cancer Res 2001, 61:3604-3609.

82. Moreira AL, Sampaio EP, Zmuidzinas A, Frindt P, Smith KA, Kaplan G: Thalidomide exerts its inhibitory action on tumous necrosis factor by enhancing mRNA degradation. J Exp Med 1993, I77:1675-1680.

83. Gordon JN, Trebble TM, Ellis RD, Duncan HD, Johns T, Goggin PM: Thalidomide in the treatment of cancer cachexia: a randomised placebo controlled trial. Gut 2005, 54:540-545.

84. Boddaert MS, Gerritsen WR, Pinedo HM: On our way to targeted therapy for cachexia in cancer? Curr Opin Oncol 2006, I 8:335-340.

85. Dezube BJ, Sherman ML, Fridovich-Keil JL, Allen-Ryan J, Pardee AB: Down-regulation of tumor necrosis factor expression by pentoxifylline in cancer patients: a pilot study. Cancer Immunol Immunother 1993, 36:57-60.

86. Combaret L, Ralliere C, Taillandier D, Tanaka K, Attaix D: Manipulation of the ubiquitin-proteasome pathway in cachexia: pentoxifylline suppresses the activation of 205 and 265 proteasomes in muscles from tumor-bearing rats. $\mathrm{Mol} \mathrm{Biol}$ Rep 1999, 26:95-101.

87. Goldberg RM, Loprinzi CL, Mailliard JA, O'Fallon JR, Krook JE, Ghosh C. Hestorff RD, Chong SF, Reuter NF, Shanahan TG: Pentoxifylline for treatment of cancer anorexia and cachexia? $A$ randomized, double-blind, placebo-controlled trial. J Clin Oncol 1995, I 3:2856-2859.

88. Combaret L, Tilignac T, Claustre A, Voisin L, Taillandier D, Obled C, Tanaka K, Attaix D: Torbafylline (HWA 448) inhibits enhanced skeletal muscle ubiquitin- proteasome-dependent proteolysis in cancer and septic rats. Biochem J 2002, 36 I: I85-192.

89. Yimlamai T, Dodd SL, Borst SE, Park S. Clenbuterol induces muscle-specific attenuation of atrophy through effects on the ubiquitin-proteasome pathway. J Appl Physiol 2005, 99:7I-80.

90. Ryall JG, Plant DR, Gregorevic P, Sillence MN, Lynch GS: Beta 2 agonist administration reverses muscle wasting and improves muscle function in aged rats. J Physiol 2004, 555:175-188.

9I. Busquets S, Figueras MT, Fuster G, Almendro V, Moore-Carrasco R, Ametller E, Argiles JM, Lopez-Soriano FJ: Anticachectic effects of 
formoterol: a drug for potential treatment of muscle wasting. Cancer Res 2004, 64:6725-673I.

92. Hoffman RJ, Hoffman RS, Freyberg CL, Poppenga RH, Nelson LS: Clenbuterol ingestion causing prolonged tachycardia, hypokalemia, and hypophosphatemia with confirmation by quantitative levels. J Toxicol Clin Toxicol 200I, 39:339-344.

93. Wyke SM, Russell ST, Tisdale MJ: Induction of proteasome expression in skeletal muscle is attenuated by inhibitors of NF-kappaB activation. Br J Cancer 2004, 9 I: I742- 1750.

94. Fischer D, Gang G, Pritts T, Hasselgren PO: Sepsis-induced muscle proteolysis is prevented by a proteasome inhibitor in vivo. Biochem Biophys Res Commun 2000, 270:215-22I.

95. Chauhan D, Hideshima T, Anderson KC: Proteasome inhibition in multiple myeloma: therapeutic implication. Annu Rev Pharmacol Toxicol 2005, 45:465-476.

96. Jones SW, Hill RJ, Krasney PA, O'Conner B, Peirce N, Greenhaff PL: Disuse atrophy and exercise rehabilitation in humans profoundly affects the expression of genes associated with the regulation of skeletal muscle mass. Faseb J 2004, 18:1025-1027.

97. Moore-Carrasco R: The AP-I/cJUN signaling cascade is involved in muscle differentiation: implications in muscle wasting during cancer cachexia. FEBS Lett 2006, 580:69I-696.

98. Li YP, Chen Y, John J, Moylan J, Jin B, Mann DL, Reid MB: TNF-alpha acts via p38 MAPK to stimulate expression of the ubiquitin ligase atrogin I/MAFbx in skeletal muscle. Faseb J 2005, 19:362-370.

99. Nalepa G, Rolfe M, Harper JW: Drug discovery in the ubiquitinproteasome system. Nat Rev Drug Discov 2006, 5:596-6/3.

100. Khal J, Wyke SM, Russell ST, Hine AV, Tisdale MJ: Expression of the ubiquitin-proteasome pathway and muscle loss in experimental cancer cachexia. Br J Cancer 2005, 93:774-780.

101. Wray CJ, Mammen JM, Hershko DD, Hasselgren PO: Sepsis upregulates the gene expression of multiple ubiquitin ligases in skeletal muscle. Int J Biochem Cell Biol 2003, 35:698-705.

102. Voisin L, Breuille D, Combaret L, Pouyet C, Taillandier D, Aurousseau $E$, Obled $C$, Attaix $D$ : Muscle wasting in a rat model of longlasting sepsis results from the activation of lysosomal, $\mathrm{Ca2+-}$ activated, and ubiquitin-proteasome proteolytic pathways. J Clin Invest 1996, 97:1610-1617.

103. Taillandier D, Aurousseau E, Combaret L, Guezennec CY, Attaix D: Regulation of proteolysis during reloading of the unweighted soleus muscle. Int J Biochem Cell Biol 2003, 35:665-675.

104. Batt J, Bain J, Goncalves J, Michalski B, Plant P, Fahnestock M, Woodgett J: Differential gene expression profiling of short and long term denervated muscle. Faseb / 2006, 20:115-1I7.

105. Lecker SH, Solomon V, Price SR, Kwon YT, Mitch WE, Goldberg AL: Ubiquitin conjugation by the $\mathrm{N}$-end rule pathway and mRNAs for its components increase in muscles of diabetic rats. J Clin Invest 1999, 104: I4I I- I 420.

106. Duan X, Berthiaume F, Yarmush D, Yarmush ML: Proteomic analysis of altered protein expression in skeletal muscle of rats in a hypermetabolic state induced by burn sepsis. Biochem J 2006, 397:149-158.

107. Pereira C, Murphy K, Jeschke M, Herndon DN: Post burn muscle wasting and the effects of treatments. Int J Biochem Cell Biol 2005, 37:1948-1961.

108. Lin SY, Chen WY, Lee FY, Huang CJ, Sheu WH: Activation of ubiquitin-proteasome pathway is involved in skeletal muscle wasting in a rat model with biliary cirrhosis: potential role of TNF-alpha. Am J Physiol Endocrinol Metab 2005, 288:E493-50I.

109. Dasarathy S, Dodig M, Muc SM, Kalhan SC, McCullough AJ: Skeletal muscle atrophy is associated with an increased expression of myostatin and impaired satellite cell function in the portacaval anastamosis rat. Am J Physiol Gastrointest Liver Physiol 2004, 287:GI I24-II30.

1 10. Kee AJ, Combaret L, Tilignac T, Souweine B, Aurousseau E, Dalle M, Taillandier D, Attaix D: Ubiquitin-proteasome-dependent muscle proteolysis responds slowly to insulin release and refeeding in starved rats. J Physiol 2003, 546:765-776.

III. Argiles JM, Busquets S, Garcia-Martinez C, Lopez-Soriano FJ: Mediators involved in the cancer anorexia-cachexia syndrome: past, present, and future. Nutrition 2005, $21: 977-985$.

112. Liu Z, Miers WR, Wei L, Barrett EJ: The ubiquitin-proteasome proteolytic pathway in heart vs skeletal muscle: effects of acute diabetes. Biochem Biophys Res Commun 2000, 276: I 255-I 260.
1 13. Du J, Mitch WE: Identification of pathways controlling muscle protein metabolism in uremia and other catabolic conditions. Curr Opin Nephrol Hypertens 2005, 14:378-382.

I 14. Roest HP, van Klaveren J, de Wit J, van Gurp CG, Koken MH, Vermey $M$, van Roijen JH, Hoogerbrugge JW, Vreeburg JT, Baarends WM, Bootsma D, Grootegoed JA, Hoeijmakers JH: Inactivation of the HR6B ubiquitin-conjugating DNA repair enzyme in mice causes male sterility associated with chromatin modification. Cell 1996, 86:799-8I0.

115. Messina S, Bitto A, Aguennouz M, Minutoli L, Monici MC, Altavilla D, Squadrito F, Vita G: Nuclear factor kappa-B blockade reduces skeletal muscle degeneration and enhances muscle function in Mdx mice. Exp Neurol 2006, 198:234-24I.

1 16. Kamei Y, Miura S, Suzuki M, Kai Y, Mizukami J, Taniguchi T, Mochida K, Hata T, Matsuda J, Aburatani H, Nishino I, Ezaki O: Skeletal muscle FOXOI (FKHR) transgenic mice have less skeletal muscle mass, down-regulated Type I (slow twitch/red muscle) fiber genes, and impaired glycemic control. J Biol Chem 2004, 279:4 II|4-4|| 23.

\section{Publication history}

Republished from Current BioData's Targeted Proteins database (TPdb; http://www.targetedproteinsdb.com).
Publish with Bio Med Central and every scientist can read your work free of charge

"BioMed Central will be the most significant development for disseminating the results of biomedical research in our lifetime. "

Sir Paul Nurse, Cancer Research UK

Your research papers will be:

- available free of charge to the entire biomedical community

- peer reviewed and published immediately upon acceptance

- cited in PubMed and archived on PubMed Central

- yours - you keep the copyright

Submit your manuscript here:

http://www.biomedcentral.com/info/publishing_adv.asp
BioMedcentral 